\title{
Effect of Smoking on Polycyclic Aromatic Hydrocarbons (PAHS) Concentrations in Catfish and Tilapia Muscles
}

\author{
${ }^{* 1}$ NNAJI, JC; EKWE, NP \\ Department of Chemistry, Michael Okpara University of Agriculture, Umudike, \\ P.M.B 7267, Umuahia, Abia State, Nigeria
}

\begin{abstract}
The effects of smoking on proximate composition, energy values and concentrations of polycyclic aromatic hydrocarbons (PAHs) were studied in raw and smoked samples of catfish (Clarias gariepinus) and tilapia (Oreochromis niloticus). Crude protein was higher in the tilapia sample for both raw and smoked samples. There was significant difference $(\mathrm{P}<0.05)$ in the lipid contents of raw and smoked samples of both species. Mean naphthalene concentration was significantly higher $(\mathrm{P}<0.05)$ than those of other PAHs analyzed in raw and smoked samples of both species. Mean benzo (a) pyrene (BaP) concentrations and total mean PAH concentrations $(\Sigma \mathrm{mPAH})$ exceeded the EU limits in raw muscle samples. All the PAHs analyzed were detected in the smoked samples. Mean BaP concentrations and total mean PAH exceeded the EU maximum limits $(2.0$ and $10 \mu \mathrm{g} / \mathrm{kg})$ in the muscle of smoked fish and fishery products. Total mean concentration of the four indicators of PAH contamination gave the values of 0.018 and $0.050 ; 0.014$ and $0.012 \mathrm{mg} / \mathrm{kg}$ for raw and smoked samples of catfish and tilapia respectively. It could be inferred that the smoking process generally increased the mean total PAH levels in the fish samples and there is urgent need for relevant authorities to take appropriate action due to the public health implications of PAH contamination.
\end{abstract}

DOI: https://dx.doi.org/10.4314/jasem.v22i2.23

Copyright: Copyright (C) 2018 Nnaji and Ekwe. This is an open access article distributed under the Creative Commons Attribution License (CCL), which permits unrestricted use, distribution, and reproduction in any medium, provided the original work is properly cited

Dates: Received: 15 September 2017; Revised: 22 November 2017; Accepted: 14 February 2018

Keywords: catfish, tilapia, smoking, hydrocarbons, gas chromatography

Fish is consumed by a large number of people because of its palatability, flavour and availability (Foran et al., 2005). It gives protein improved nutrition because it has high biological value in terms of high protein retention in the body (Anthony and Akinwumi, 1999). It also contains some bioactive compounds with therapeutic properties that are beneficial to human health (Nnaji et al., 2010).

Smoke is generated by among others, thermal pyrolysis of hard wood when there is limited access to oxygen. Fish processing by traditional method of smoking enables fish to have stability during storage, increases their appetizing appeal, gives special organoleptic profiles to smoked products, and smoking is also done because of the inactivating effect of smoke (and heat) on enzymes and microorganisms (Chen and Lin, 1997). However, this processing method may have negative impacts on consumer health due to the fact that smoking may lead to the deposition of polycyclic aromatic hydrocarbons (PAHs) on smoked fish.

PAHs are environmental contaminants, originating from incomplete combustion of organic matter (Jira et al., 2006; Klimaszewska, 1999). They are formed when complex organic substances are exposed to high temperature or pressure or by the incomplete combustion of woods, coal or oil (Easton et al., 2002; Storelli et al., 2003; Groova et al., 2005; Wretling et $a l ., 2010)$. Food can be contaminated by PAHs that are present in air, soil, or water, or during food processing and cooking. PAHs are also found in water though they are hydrophobic (especially heavy PAHs). It is estimated that nearly $70 \%$ of PAHs are consumed with food, including the consumption of smoked fish. Of the several hundreds of PAHs, sixteen have been identified as priority PAHs because they have been considered to be more harmful to man than the others (Andrzej and Zdzislaw, 2005; Anyakora and Herbert, 2005).

\section{MATERIALS AND METHODS}

Sampling: Raw samples of two local freshwater species, Catfish (Clarias gariepinus), and Nile Tilapia (Oreochromis niloticus) were harvested from Michael Okpara University of Agriculture, Umudike (MOUAU) fish pond and were smoked at Ahiaeke market in Umuahia. Triplicate samples of each fish species of similar weights were collected for analysis.

Sample pre-treatment: The standard and total lengths of raw samples were measured with a meter rule while their weights were determined with a balance. Each triplicate sample was divided into two with a stainless steel knife, one half was sent to Ahiaeke Market for smoking, while the other was used for raw sample analysis. The raw samples were stored at $20^{\circ} \mathrm{C}$ in a refrigerator prior to analysis. The lipid extraction of fish muscle samples was done in the Chemistry Laboratory of Michael Okpara University of Agriculture, Umudike. The extracted solution was 
then sent to BGI laboratories Ltd, Elelenwo, Port Harcourt where the GC/MS analysis was carried out.

The fish smoking process: Tilapia was descaled and together with catfish was washed with clean tap water. They were subsequently rinsed with distilled water and were brined with $10 \%$ salt solution and placed on wire gauze placed on drum type smoking kiln. Wood served as fuel and a distance of $30 \mathrm{~cm}$ was maintained between fish and the flame. Smoking temperature was measured with a mercury-in-glass thermometer and smoking was done for a period of 6 $\mathrm{h}$ after which the fish was allowed to cool for $1 \mathrm{~h}$ and wrapped in polyethylene bags prior to $\mathrm{PAH}$ analysis.

Determination of proximate composition and energy value: Proximate analysis of fish was done with the method of FAO (1994). This includes the determination of moisture, crude fat, crude protein, crude ash, crude fibre, and nitrogen free extracts. The energy value was calculated by using the Atwater general factor system which assigns energy values of $17 \mathrm{~kJ} / \mathrm{g}(4.0 \mathrm{kcal} / \mathrm{g})$ for protein, $37 \mathrm{~kJ} / \mathrm{g}(9.0 \mathrm{kcal} / \mathrm{g})$ for fat and $17 \mathrm{~kJ} / \mathrm{g}(4.0 \mathrm{kcal} / \mathrm{g})$ for carbohydrates and $29 \mathrm{~kJ} / \mathrm{g}(7.0 \mathrm{kcal} / \mathrm{g}$ ) for alchohols (Scott, 2014). The total combination of ratio is $4: 4: 9$ for protein, carbohydrate (NFE) and lipids. The weight of the fish in grams is obtained and each percentage proximate composition is multiplied by the weight of the fish to get the weight of protein, fat and carbohydrate in $\mathrm{g}$. Then each weight is multiplied by the proper factor in the ratio and results summed to give the total energy value in calories.

Soxhlet extraction method: Homogenized fish muscle sample (10 g) was weighed and mixed thoroughly with $5 \mathrm{~g}$ of anhydrous sodium sulphate in a laboratory crucible until a complete homogenate was obtained. The extraction was carried out using a Soxhlet extractor apparatus which consists of a $250 \mathrm{~cm}^{3}$ round bottomed flask, condenser and an extractor tube, seated in a temperature-controlled heating mantle. The homogenate was carefully transferred into the extraction thimble placed in the extraction chamber of the Soxhlet extraction unit. The extraction was carried out as recommended by USEPA 3540 method, using $150 \mathrm{~cm}^{3}$ dichloromethane for $16 \mathrm{~h}$ (USEPA, 1996). The extract was concentrated to 2 $\mathrm{cm}^{3}$ using a Fischer brand rotary evaporator in a water bath that was pre-set to a temperature of $35^{\circ} \mathrm{C}$ and was stored in an amber bottle and kept in a refrigerator to avoid oxidation of the extract prior to clean up. The same procedure was used for all the fish samples collected.

Sample purification: The extracted samples were purified by passing them through a silica gel column prepared by loading $10 \mathrm{~g}$ of activated silica gel (100$200 \mathrm{Mesh})$ onto a chromatographic column $(1 \mathrm{~cm}$ internal diameter) to $5 \mathrm{~cm}$. This was topped with $1 \mathrm{~cm}$ of anhydrous $\mathrm{Na}_{2} \mathrm{SO}_{4}$ was then conditioned with dichloromethane. $2 \mathrm{~cm}^{3}$ of the concentrated extract was loaded and eluted with $20 \mathrm{~cm}^{3}$ of dichloromethane. This method is able to remove the very polar lipids off the extract. Prior to analysis with GC/MS, the extracts obtained were preserved in an amber bottle to avoid oxidation.

GC/MS Analysis: An Agilent 7890 Gas Chromatograph equipped with auto sampler connected to an Agilent 5975 MSD mass spectrometric detector was used. $1 \mu 1$ of sample solution was injected in the pulsed spilt less mode onto a $30 \mathrm{~mm} \times 0.25 \mathrm{~mm}$ id DB5 MS coated fused silica column with a film thickness of $0.15 \mu \mathrm{m}$. Helium was used as the carrier gas and the column head pressure was maintained at $20 \mathrm{psi}$ to give constant flow $1 \mathrm{ml} / \mathrm{min}$. Other operating conditions were pre-set, pulse time $0.90 \mathrm{~min}$, purge flow $50 \mathrm{~cm}^{3}$, purge time $1 \mathrm{~min}$, and injection temperature $300{ }^{\circ} \mathrm{C}$. The column temperature was initially held at $55{ }^{\circ} \mathrm{C}$ for $0.4 \mathrm{~min}$, increased to $200{ }^{\circ} \mathrm{C}$ at a rate of 25 ${ }^{\circ} \mathrm{C} / \mathrm{min}$, then to $280{ }^{\circ} \mathrm{C}$ at a rate of $8{ }^{\circ} \mathrm{C} / \mathrm{min}$ and to a final temperature of $300{ }^{\circ} \mathrm{C}$ at a rate of $25^{\circ} \mathrm{C} / \mathrm{min}$ and held for $2 \mathrm{~min}$ at transfer line of $320{ }^{\circ} \mathrm{C}$. The mass spectrometer (MS) condition was electron impact positive ion mode. The PAHs identification time was based on retention time since each of the PAHs has its separate retention time in the column. Those with lower retention times were identified first followed by those with longer retention times. The GC/MS was calibrated with calibration standard concentration purchased from Accuu standard, USA. PAHs were identified by comparing the retention times of the peaks with those obtained from standard mixture of PAHs. The standards were supplied by the instrument manufacturers.

Statistical analysis: The PAH analysis was carried out for each sample in triplicate $(n=3)$. The obtained results were statistically analysed using SPSS (version 20.0) windows software. Mean concentration and standard error of the mean (S.E.M) were calculated for each parameter. The result was subjected to one way ANOVA and the means were compared using Duncan multiple Range test.

\section{RESULTS AND DISCUSSION}

Table 1 shows the mean standard and total lengths of fish and the mean weights of fish species used in the study. Mean values for weights and standard lengths were similar $(\mathrm{P}>0.05)$ but total length of Tilapia was significantly lower $(\mathrm{P}<0.05)$ than that of catfish.

\begin{tabular}{lll}
\multicolumn{3}{l}{ Table 1 Mean weights and lengths of raw fish samples } \\
\hline Parameter & $\begin{array}{l}\text { Catfish (Clarias } \\
\text { gariepinus) }\end{array}$ & $\begin{array}{l}\text { Nile Tilapia } \\
\text { (Oreochromis } \\
\text { niloticus) }\end{array}$ \\
\hline $\begin{array}{l}\text { Standard length } \\
(\mathrm{cm})\end{array}$ & $6.15 \pm 0.27$ & $5.68 \pm 0.90$ \\
$\begin{array}{l}\text { Total length }(\mathrm{cm}) \\
\text { Weight }(\mathrm{g})\end{array}$ & $8.20 \pm 0.83$ & $6.45 \pm 0.73$ \\
& $122.47 \pm 1.07$ & $120.95 \pm 0.95$ \\
\hline
\end{tabular}


Table 2 shows the mean temperatures at which the fish species were smoked and energy values for raw and smoked samples. There were no significant differences $(\mathrm{P}<0.05)$ in smoking temperatures and energy values for raw and smoked samples.

Table 2 Mean smoking temperatures and energy values (cal) for each species

\begin{tabular}{llll}
\hline Sample & Mean & & \\
\cline { 3 - 4 } & Smoking & Mean energy values (cal) & \\
\cline { 3 - 4 } & Temperature & & Rmoked \\
& $\left({ }^{\circ} \mathrm{C}\right)$ & & \\
Catfish & $72.27 \pm 3.41$ & $416.936 \pm 0.075$ & $415.780 \pm 0.051$ \\
Tilapia & $70.39 \pm 4.59$ & $408.297 \pm 0.043$ & $407.587 \pm 0.024$ \\
\hline
\end{tabular}

Table 3 presents the proximate composition of analyzed fish samples. The result reveal significant differences $(\mathrm{P}<0.05)$ in moisture content, crude protein, ash content, crude lipid and crude fibre among the samples. As expected, moisture content was higher in the raw samples compared to their corresponding smoked samples. This observation is due to loss of water during smoking (Salan et al., 2006). The highest moisture content was recorded in fresh tilapia sample. Crude protein was also higher in the tilapia sample for both raw and smoked samples. Crude fibre, lipid and ash contents were significantly higher $(\mathrm{P}<0.05)$ in smoked muscle samples than in raw samples of both species.

The results of mean concentration for each $\mathrm{PAH}$ in raw samples are shown in table 4 .

Table 3: Proximate composition of raw and smoked samples

\begin{tabular}{lllll}
\hline Proximate & \multicolumn{2}{c}{ Catfish } & \multicolumn{2}{c}{ Tilapia } \\
\cline { 2 - 5 } Analysis & Raw & Smoked & Raw & Smoked \\
& 75.69 & 62.07 & 78.49 & 66.74 \\
Moisture content & $\pm 0.02^{\mathrm{a} 1}$ & $\pm 0.01^{\mathrm{a} 2}$ & $\pm 0.02^{\mathrm{a} 1}$ & $\pm 0.01^{\mathrm{a} 2}$ \\
& 16.97 & 19.49 & 31.68 & 40.61 \\
Crude protein & $\pm 0.01^{\mathrm{b} 1}$ & $\pm 0.01^{\mathrm{b} 1}$ & $\pm 0.01^{\mathrm{b} 2}$ & $\pm 0.01^{\mathrm{b} 3}$ \\
& 0.28 & 1.18 & 0.45 & 1.64 \\
Crude fibre & $\pm 0.01^{\mathrm{c} 1}$ & $\pm 0.01^{\mathrm{c} 2}$ & $\pm 0.01^{\mathrm{c} 1}$ & $\pm 0.01^{\mathrm{c} 2}$ \\
& 4.90 & 8.77 & 3.15 & 6.92 \\
Crude lipid & $\pm 0.01^{\mathrm{d} 1}$ & $\pm 0.00^{\mathrm{d} 2}$ & $\pm 0.01^{\mathrm{d} 1}$ & $\pm 0.01^{\mathrm{d} 2}$ \\
& 1.61 & 5.83 & 1.42 & 5.11 \\
Ash & $\pm 0.01^{\mathrm{c} 1}$ & $\pm 0.00^{\mathrm{d} 2}$ & $\pm 0.01^{\mathrm{c} 1}$ & $\pm 0.00^{\mathrm{d} 2}$ \\
& 76.25 & 64.73 & 63.31 & 45.74 \\
Nitrogen free extracts & $\pm 0.03^{\mathrm{a} 1}$ & $\pm 0.02^{\mathrm{a} 2}$ & $\pm 0.03^{\mathrm{e} 2}$ & $\pm 0.033^{\mathrm{b} 3}$ \\
(NFE) & & & & \\
\hline
\end{tabular}

Means with different numbers (letters) in the same row (column) are significantly different $(\mathrm{P}<0.05)$. Data are presented as Mean \pm S.E.M.

Table 4: Mean PAH concentrations $(\mathrm{mg} / \mathrm{kg})$ in raw samples

\begin{tabular}{llc}
\hline PAHs & Catfish & Tilapia \\
\hline Naphthalene & $63.904 \pm 0.118^{\mathrm{al}}$ & $39.705 \pm 0.099^{\mathrm{a} 2}$ \\
Acenaphthylene & $0.166 \pm 0.001^{\mathrm{b} 1}$ & $0.000 \pm 0.000$ \\
Acenaphthene & $0.326 \pm 0.002^{\mathrm{b} 1}$ & $0.136 \pm 0.002^{\mathrm{b} 2}$ \\
Fluorene & $0.059 \pm 0.005^{\mathrm{c} 1}$ & $0.004 \pm 0.001^{\mathrm{c} 2}$ \\
Anthracene & $0.063 \pm 0.002^{\mathrm{cl}}$ & $0.012 \pm 0.005^{\mathrm{c} 2}$ \\
Phenanthrene & $0.067 \pm 0.001^{\mathrm{c} 1}$ & $0.021 \pm 0.001^{\mathrm{c} 2}$ \\
Fluoranthene & $0.017 \pm 0.001^{\mathrm{d} 1}$ & $0.004 \pm 0.001^{\mathrm{c} 2}$ \\
Pyrene & $0.004 \pm 0.002^{\mathrm{d} 1}$ & $0.002 \pm 0.000^{\mathrm{c} 1}$ \\
Benz[a]anthracene & $0.006 \pm 0.002^{\mathrm{d} 1}$ & $0.004 \pm 0.001^{\mathrm{cl}}$ \\
Chrysene & $0.002 \pm 0.001^{\mathrm{d} 1}$ & $0.002 \pm 0.001^{\mathrm{cl}}$ \\
Benzo[b]Fluoranthene & $0.005 \pm 0.001^{\mathrm{d} 1}$ & $0.003 \pm 0.001^{\mathrm{cl}}$ \\
Benzo[k]Fluoranthene & $0.004 \pm 0.001^{\mathrm{d} 1}$ & $0.004 \pm 0.001^{\mathrm{cl}}$ \\
Benzo[a]Pyrene & $0.005 \pm 0.002^{\mathrm{d} 1}$ & $0.005 \pm 0.001^{\mathrm{cl}}$ \\
Dibenz[a,h]anthracene & $0.001 \pm 0.001^{\mathrm{d} 1}$ & $0.000 \pm 0.000$ \\
Indenol[1,2,3-c,d] Pyrene & $0.016 \pm 0.001^{\mathrm{d} 1}$ & $0.013 \pm 0.001^{\mathrm{cl}}$ \\
Benzo[g,h,i]perylene & $0.015 \pm 0.000$ & $0.000 \pm 0.000$ \\
EMpah & 64.672 & 39.915 \\
EPAH4 & 0.018 & 0.014 \\
\hline
\end{tabular}

$\sum \mathrm{mPAH}=$ total mean PAH, $\Sigma \mathrm{PAH} 4=$ sum of the four indicator PAHs. Means with different numbers (letters) in the same row (column) are significantly different $(\mathrm{P}<0.05)$. Values are mean \pm S.E.M for three replicates, $(n=3)$

From the results, it can be seen that naphthalene, acenaphthylene and acenaphthene were predominant in all the samples. Naphthalene concentration was significantly higher $(\mathrm{P}<0.05)$ than those of other PAHs analyzed in both species. All the 16 targeted PAHs were detected in all the raw samples except acenaphthylene, dibenz(a,h)anthracene and benzo(g,h,i)perylene which were not detected in Tilapia. Benzo[a]Pyrene (BaP) concentrations were within the range of 1.5 and $10.5 \mu \mathrm{g} \mathrm{kg}^{-1}$ observed in a study of $\mathrm{BaP}$ concentrations in four different fish samples from the Niger delta area of Nigeria (Anyakora et al., 2008).

Catfish had the highest value of $64.672 \mathrm{mg} / \mathrm{kg}$ for total mean PAH ( $\left.\sum \mathrm{mPAH}\right)$ and sum of PAH4 $(\Sigma \mathrm{PAH} 4)$ was also higher in catfish. The EU maximum limits for benzo(a)pyrene and total PAHs 
in the muscle of smoked fish and fishery products are $2.0 \mu \mathrm{g} / \mathrm{kg}$ and $10 \mu \mathrm{g} / \mathrm{kg}$ respectively (EFSA, 2008). Mean BaP concentrations were above the limit and $\sum \mathrm{mPAH}$ values also exceeded the EU limit in both species which is attributed to the high naphthalene concentrations. The high levels of $\mathrm{PAH}$ in raw fish muscle can be attributed to the fish rearing process, possibly through the ingestion of PAH contaminated fish feed.

Mean PAH concentrations for each PAH in smoked fish samples are shown in table 5.

Table 5: Mean PAH concentrations $(\mathrm{mg} / \mathrm{kg})$ in smoked fish samples

\begin{tabular}{|c|c|c|}
\hline PAHs & Catfish & Tilapia \\
\hline Naphthalene & $68.966 \pm 0.423^{\mathrm{al}}$ & $41.447 \pm 0.066^{\mathrm{a} 2}$ \\
\hline Acenaphthylene & $0.008 \pm 0.001^{\mathrm{b} 1}$ & $0.132 \pm 0.003^{\mathrm{b} 2}$ \\
\hline Acenaphthene & $0.384 \pm 0.036^{\mathrm{cl}}$ & $0.328 \pm 0.013^{\mathrm{bl}}$ \\
\hline Fluorene & $0.058 \pm 0.002^{\mathrm{d} 1}$ & $0.052 \pm 0.003^{\mathrm{cl}}$ \\
\hline Anthracene & $0.058 \pm 0.001^{\mathrm{d} 1}$ & $0.048 \pm 0.001^{\mathrm{cl}}$ \\
\hline Phenanthrene & $0.060 \pm 0.001^{\mathrm{d} 1}$ & $0.049 \pm 0.003^{\mathrm{cl}}$ \\
\hline Fluoranthene & $0.012 \pm 0.002^{\mathrm{b} 1}$ & $0.010 \pm 0.001^{\mathrm{d} 1}$ \\
\hline Pyrene & $0.005 \pm 0.001^{\mathrm{b} 1}$ & $0.003 \pm 0.001^{\mathrm{d} 1}$ \\
\hline Benz[a]anthracene & $0.003 \pm 0.001^{\mathrm{b} 1}$ & $0.003 \pm 0.001^{\mathrm{d} 1}$ \\
\hline Chrysene & $0.002 \pm 0.001^{\mathrm{b} 1}$ & $0.002 \pm 0.001^{\mathrm{d} 1}$ \\
\hline Benzo[b]Fluoranthene & $0.005 \pm 0.001^{\mathrm{b} 1}$ & $0.003 \pm 0.001^{\mathrm{d} 1}$ \\
\hline Benzo[k]Fluoranthene & $0.005 \pm 0.001^{\mathrm{b} 1}$ & $0.003 \pm 0.001^{\mathrm{d} 1}$ \\
\hline Benzo[a]Pyrene & $0.040 \pm 0.030^{\mathrm{d} 1}$ & $0.004 \pm 0.002^{\mathrm{d} 2}$ \\
\hline Dibenz[a,h]anthracene & $0.011 \pm 0.001^{\mathrm{b} 1}$ & $0.008 \pm 0.002^{\mathrm{d} 1}$ \\
\hline Indenol[1,2,3-cd] Pyrene & $0.014 \pm 0.001^{\mathrm{b} 1}$ & $0.013 \pm 0.002^{\mathrm{d} 1}$ \\
\hline Benzo[g,h,1]perylene & $0.014 \pm 0.001^{\mathrm{b} 1}$ & $0.010 \pm 0.003^{\mathrm{d} 1}$ \\
\hline$\sum \mathrm{mPAH}$ & 69.645 & 42.115 \\
\hline$\sum \mathrm{PAH} 4$ & 0.05 & 0.012 \\
\hline
\end{tabular}

$\sum \mathrm{mPAH}=$ total mean PAH, $\overline{\sum \mathrm{PAH} 4=\text { sum of the four indicator PAHs. Means with different numbers (letters) }}$ in the same row (column) are significantly different $(\mathrm{P}<0.05)$. Values are mean \pm S.E.M for three replicates, $(n=3)$

All the PAHs analyzed were detected in the smoked samples. Naphthalene concentrations were significantly higher $(\mathrm{P}<0.05)$ than the concentrations of other PAHs. Mean BaP concentrations and total mean PAH exceeded the EU maximum limits (2.0 and $10 \mu \mathrm{g} / \mathrm{kg}$ ) in the muscle of smoked fish and fishery products. A study of PAH concentrations in fish obtained values of 86.1 and $1026.9 \mu \mathrm{g} / \mathrm{kg}$ dry weight for raw and commercially smoked mudfish (Clarias gariepinus) and 104.1 and $611.4 \mu \mathrm{g} / \mathrm{kg}$ dry weight for raw and commercially smoked mackerel (Scomber scombrus) (Akpambang et al., 2009). These values are less than the values for total PAHs obtained in this study. Another study obtained a BaP concentration of $6.48 \times 10^{-5}$ and $5.205 \times 10^{-4} \mathrm{mg} / \mathrm{kg}$ in freshly and long processed fish samples and these values are lower than results from this study (Ujowundu et al., 2014). BaP concentrations ranging from 35.5 to $139 \mu \mathrm{g} / \mathrm{kg}$ dry weight were also found in fish smoked with traditional smoking method (Akpan et al., 1994).

Mean chrysene and Benz (b)fluoranthene concentrations were similar $(\mathrm{P}>0.05)$ in both raw and smoked samples. Dibenz $(\mathrm{a}, \mathrm{h})$ anthracene and benzo(g,h.i)perylene were not detected in raw tilapia sample but were detected in the smoked tilapia sample. Mean chrysene, benzo (b)fluoranthene and indenol(1,2,3-cd)pyrene concentrations did not change, which shows that they were not affected by the smoking process. However, benz(a)anthracene, benzo(a)pyrene and benz(k)fluoranthene were all higher in the raw tilapia sample than in the smoked, which means that the smoking process may have reduced them.

Conclusion: The study revealed that the smoking process increased PAH levels in the Catfish and Tilapia muscles such that mean benzo (a) pyrene concentrations and total mean PAH concentrations exceeded the European Union limits. It is recommended that public health authorities (Abia State Ministry of Health, Federal Ministry of health, National Agency for Food Drugs Administration and Control-NAFDAC etc.) should control and set standards for fish rearing and processing in Abia State and Nigeria due to the associated public health risks.

Acknowledgements: The authors are grateful to staff of Michael Okpara University of Agriculture, Umudike (MOUAU) Fish Farm for providing the fish samples and staff of Chemistry Department Laboratory, MOUAU where extraction and proximate analyses were done and to Mr. Austin Egwu for the $\mathrm{GC}$ analyses at BGC Laboratories.

\section{REFERENCES}

Foran, JA; Carpenter, DO; Hamilton, MC; Knuth, BA; Schwager, SJ (2005). Risk-based consumption advice for farmed Atlantic and wild Pacific salmon contaminated with dioxins and dioxin-like compounds. Environ. Health Perspect. 33: 552-556. 
Anthony, OR; Akinwumi, JA (1991). Supply and distribution of fish in. Ibadan, Nigeria. Geo. J. 14(2): 16.

Nnaji, JC; Okoye, FC; Omeje, VO (2010). Screening of leaf meals as feed supplements in the culture of Oreochromis niloticus. Afr. J. Food Agric. Nutr. Dev. 10(2): 2112-2123.

Chen, BH; Lin, YS (1997). Formation of Polycyclic Aromatic Hydrocarbons during Processing of Duck Meat. J. Agric. Food Chem. 45: 13941403.

Jira, W; Ziegenhal, K; Speer, K (2006). PAK in geräucherten Fleischerzeugnissen. Untersuchungen nach den neuen EUAnforderungen. EU-Anforderungen. Fleischwirtschaft 86(10):103-106.

Klimaszewska, K (1999). Właściwości, występowanie i przemiany wielopierścieniowych węglowodorów aromatycznych w środowisku naturalnym. Żywność, Żywienie a Zdrowie 8: 363-376.

Easton, MDL; Luszniak, D; Von der Geest, E (2002). Preliminary examination of contaminant loadings in farmed salmon. Chemosphere 46: 1053-1074.

Storelli, MM; Stuffer, RG; Marcotrigiano, GO. Polycyclic aromatic hydrocarbons, polychlorinated biphenyls, chlorinated pesticides (DDTs), hexachlorocyclohexane and hexachlorobenzene residues in smoked sea food. J. Food Prot. 66: 1095- 1099.

Groova, N ; Monteau, F ; Le Bizec, B ; Feidt, C ; Andre, F ; Rychen, G (2005). Determination of phenanthrene and hydoxyphenanthrenes in various biological matrices at trace levels using gas chromatography coupled to mass spectrometry. J. Anal. Tox. 29: 175-181.

Wretling, S; Eriksson, A; Eskhult, GA; Larson, B (2010). Polycyclic aromatic hydrocarbons (PAHs) in Swedish smoked meat and fish. $J$. Food Comp. Anal. 23(1): 264-272.

Andrzej, S; Zdzislaw, ES (2005). Polycyclic aromatic hydrocarbons in smoked fish - a critical review. J. Food Chem. 91: 303-311.
Anyakora, C; Herbert, C (2006). Determination of polynuclear aromatic hydrocarbons (PAHs) in selected water bodies in the Niger Delta. Afr. J. Biotech. 5(21): 2024-2031.

Food and Agriculture Organization (1994). Nutrition of fish and crustaceans: A laboratory manual. GCP/RLA/102/ITA project. FAO, Rome.

Scott, CB (2014). Intermittent resistance exercise: evolution from the steady state. Central Euro. J. Sport Sc. Med. 6(2): 85-91.

United State Environmental Protection Agency (1996). Method 3540C: Soxhlet Extraction test method for evaluating solid waste. USEPA, Washington DC.

Salan, OE; Juliana, AG; Marilia, O (2006). Used of smoking to add value to Salmoned trout. Broz. Arch. Bio. Technol. 49(1): 57-62.

Anyakora, C; Arbabi, M; Coker H (2008). A screen for benzo (a) pyrene in fish samples from crude oil polluted environments. Amer. J. Env. Sc. 4: 145-150.

European Food Safety Authority (2008). Polycyclic Aromatic Hydrocarbons in Food: Scientific Opinion of the Panel on Contaminants in the Food Chain. The EFSA J. 724: 1-114.

Akpambang, V; Purcaro, G; Lajide, L; Amoo, I; Conte, L; Moret, S (2009). Determination of polycyclic aromatic hydrocarbons (PAHs) in commonly consumed Nigerian smoked/grilled fish and meat. Food Add. Contam. 26(07): 10961103.

Ujowundu, CO; Ihekweazu, KL; Alisi, CS; Ujowundu, FN; Igwe, CU (2014). Procarcinogens: Polycyclic Aromatic Hydrocarbons and Heavy Metal Content in Some Locally Processed Foods in South Eastern Nigeria. Brit. J. Appl. Sc. Technol. 4(1): 249-260.

Akpan, V; Lodovici, M; Dolara, P (1994). Polycyclic Aromatic Hydrocarbons in fresh and smoked fish samples from the three Nigerian Cities. Bull. Environ. Contam. Tox. 53: 246-253. 